\title{
Research on Agricultural Product Logistics Development Mode under Modern E-commerce Perspective
}

\author{
Yue Zhang \\ Tianjin Agricultural University, Tianjin 300384, China
}

Keywords: Modern E-Commerce, Agricultural products, Logistics, Development model.

\begin{abstract}
Agricultural products logistics is an important and indispensable component in agricultural e-commerce platform. But the supply level of agricultural products in China as a whole is still very backward, this restricts the development of agricultural e-commerce. State and government pay more and more attention to the problem of "issues of agriculture, farmer and rural area" with the related development problem of agricultural logistics also on the agenda. Our country is a big agricultural country, while our export trade is also top-ranked in the world. Therefore, reasonably solving the problem of agricultural products logistics is of great help to China's agricultural development. To build what kind of agricultural products logistics development model is of great importance.
\end{abstract}

\section{Introduction}

The modern logistics industry is an important product of the development of economy, science and technology and economic globalization at a certain stage. The development level of logistics industry is an important symbol to evaluate the modernization process and comprehensive strength of a city or region. Our country is a big agricultural country, the supply logistics, production logistics, distribution logistics and returned logistics etc. of inputs of agricultural products also have a very important role in national economy. The development of electronic commerce provides a broader development platform for the development of agricultural products logistics industry. If the modern logistics industry couldn't be developed effectively, the agriculture of China would not be able to well realize its agricultural modernization. Speeding up the development of agricultural product logistics is helpful to reduce consumption of agricultural products and improve the economic profits.

\section{The research significance, background and theoretical definition}

Our country is a big agricultural country, agriculture is the foundation for people to live. A basic link to add the value of agricultural products is to develop agricultural products logistics. Backward agricultural development, slow farmers' economic growth etc., these factors seriously restrict the expansion of domestic demand in China. One of the key points to solve this problem is agricultural products logistics. State and government in recent years has developed a series of measures to improve the rural economy continuously. Although our country's rural economy and agricultural production supply ability have been greatly improved, there are still some hidden unstable factors. The continuous development of electronic commerce speeds up the logistics development and economic benefits of other products, so problems such as agricultural products' market regulation system not sound, quality and safety not stable, price volatility, agricultural product structure not scientific, imperfect, low degree of circulation organization etc. must be solved as soon as possible to make full use of e-commerce platform to realize the economy income of agriculture and rural area marching toward a higher level. Compared with the developed countries, the development level of our country's agricultural products logistics is very backward. How to construct agricultural products logistics through combining with e-commerce platform to improve the competitiveness of our country's agricultural products in the international world is a problem needs to be solved urgently in our country. Since joining the world trade organization, the logistics industry in China has also gradually been developed to the direction of Internet economization, multinationalization and large 
scale, so the agricultural product logistics must also keep up with the development of international agricultural products logistics as soon as possible. But this also brings the operation of each link of circulation of agricultural products logistics a more serious test.

The study of agricultural products logistics in China started relatively late with the research on agricultural products logistics still limited in the research of distribution system. The construction of agricultural products logistics is an important basis of the development of China's socialist new countryside as well as an inevitable requirement for agriculture to be developed into industrialization and modernization. It is required to develop agricultural products logistics in our country vigorously and find out the problems and shortcomings appear, and improve and promote which in a timely manner to promote our country's traditional agricultural products logistics' to be changed toward the modernization direction.

\section{The current situation of the development of agricultural products logistics mode in our country}

China's agricultural products logistics mode has mainly experienced three stages of development:

The first is the initial stage of the planned economy period.

The initial stage of agricultural products logistics development in the planned economy period is from 1949 to 1949. In this time period, the agricultural products logistics experienced two stages of development, the recovery phase of the national economy and planned economy. In this period our country's agricultural products logistics had not a clear concept, was just only a single industry where circulation, storage, transportation existed alone. In this period, the agricultural products logistics was dominated by the state, the systematicness of logistics links was bad and limited to two industries, storage and transportation industry.

The second is the initial stage of economic transition period.

The time phase from 1978 to 1991 is the initial stage of agricultural products at the transition economy period. Agricultural products logistics in this period had already begun to pace toward market while logistics modes also gradually diversified. Logistics development models at this period can be divided into two patterns, cargo market dominated type and wholesale market dominated type. Agricultural products logistics links at this period got meticulous and overall optimization, while physical system gradually perfected according to the theory of system and economic benefit also improved. But at this period, the development scale of agricultural products logistics was relatively small, the logistics modes still needed to be perfected through further exploration.

The third is the rapid development stage under market-oriented economy.

Agricultural products logistics modes in this period were divided into two stages of development: One is the contractual logistics dominated mode during the period of time from 1992 to 1997, the other is the development pattern dominated by the third party from 1998 till now. During this period, the country took policy measures continuously to reduce the expense and cost of agricultural products logistics to promote the agricultural products logistics to be converted into logistics mode dominated by the third party. Agricultural products logistics broke through the traditional logistics mode and was converted into a modern agricultural products logistics mode which combines e-commerce, production, purchasing, processing and marketing as one continuously.

But the development of our country's agricultural products logistics is imbalanced. On average, our country's agricultural products' physical trading scale is relatively small, trading way backward, function single, basis poor, while compared with the other industries, unable to keep pace with the development of network and the era. Therefore, our country's agricultural products logistics mode still needs further development.

\section{The analysis of problems existing in the agricultural products logistics}

Although our country has been committed to convert the agricultural logistics from the traditional mode to modern mode, the effect is not obvious. There are still many areas continuing to use 
traditional way to trade in operators. Agricultural products logistics in our country still has a lot of problems.

The first is our country's agricultural products logistics management is relatively scattered, unable to form economies of scale. China's agricultural development level as a whole is still relatively backward, which restricts the development of agricultural products logistics industry. Agricultural products logistics in our country at present stage is also facing the contradictory issues between individual farmers and the big market. Agricultural production situation of our country at present is still in a production mode with family as the unit. This kind of production mode is small in scale with relatively low organization degree. There isn't a good connection mechanism between farmers and the market, the production and circulation can't form economies of scale.

The second is the agricultural products' trading way is backward, transaction costs high, transaction efficiency low, trade information not unblocked. Agricultural products logistics' lagging behind has lowered the market management level, that is, the comprehensive service ability of the logistics industry and the market can't be lifted up, multiple levels of trading, high cost, most use of original methods such as on-site talking about price, on-site trading when undertaking agricultural products trade. All these leads to relatively long time and high losses during the trading of agricultural products. Agricultural products trading has disadvantages of market information construction lagging behind, poor information sharing degree, unable to access to the latest production and consumption dynamics timely. The lag of market information dissemination leads to agricultural producers' not being able to adjust production structure according to the demand of the market in a timely manner. Blind production results in a lot of shortage or surplus of agricultural products, the economic interests of farmers encounter losses.

The third is the lag of the way of trade influences the expansion of the trade scale of agricultural products as well as the promotion of business efficiency. The trade of agricultural products is still in traditional trading ways such as on-site talking about price, on-site trading, forms such as auction, bidding rarely appear in the trading of agricultural products.

The fourth is, in the process of commodity circulation, the agricultural products logistics distribution is not reasonable. For example there are still no convenient traffics in some poor areas. So it is easy to make the whole logistics industry can not get a good development. In addition, some operation modes in the traditional logistics have affected the whole commodity circulation. For instance, multiple transfers of the ownership of the goods will increase the cost of trading, and so will increase the occurrence quantity of repetitive transport and the Yuhui transportation, this also affects the overall efficiency of logistics transport to a certain extent.

\section{The construction of agricultural products logistics new mode under e-commerce}

The construction of agricultural products logistics system model under e-commerce.

The circulation of agricultural products in our country needs the direct management by the administrative department of agriculture. Because the current agricultural management system has no way to provide the required dynamic effective regulation demanded by agriculture, the logistics form under the electronic commerce is also not easy to be managed. So our country's agricultural products logistics really needs the unified management of local government, only by this can the agricultural production material be allocated reasonably to help the agricultural products move towards the internationalization. At the same time, this also avoids each department acting on its own, improving the administrative situation and playing a role of government's macroeconomic regulation and control reasonably. Reasonably normalize agricultural products, formulate relevant laws and regulations and promote the development of international logistics.

In order to strengthen technologies in the international logistics field, reasonable market industry standard should be formulated and related regulations be implemented. Because our country is a big agricultural country, the logistics of China needs more reasonable planning system. We should 
support the entrance of economic subjects including farmers, private enterprises, foreign companies and sino-foreign joint ventures into the agricultural products logistics market. To improve the trade environment of our country, the advantageous position of logistics enterprises in the world trade needs to be found, losses on economy be reduced and at the same tim the rapid development of agricultural products logistics be ensured to promote the competitiveness.

The construction of agricultural products logistics of new modes under e-commerce.

a). Building an electronic virtual market of agricultural products, creating a perfect agricultural products logistics supply chain. Providing a full-service including direct online trading, auction, online payment, logistics delivery, etc. for each link of agricultural products by using the platform mode of B to B and B to C. Establishing an agricultural production logistics supply chain in agricultural means of production including planting owners, manufacturers, suppliers, wholesale, retail etc. to make agricultural production information be able to be spreaded very quickly, be more transparent, high share to reduce the agricultural product price difference caused by the information asymmetry; Adjusting the management of the logistics planning in time, the electronicalization of agricultural products' trade can provide comprehensive services directly to global customers. Establishing a complete and concise agricultural products logistics supply chain can comprehensively improve the structure of agricultural products logistics as well as improve operational efficiency, reduce cost and improve the economies of scale and the competitive capacity.

b). Creating agricultural products logistics center, focusing on the agriculture information construction which has business-oriented, networked, digitalized characteristics. Establishing a standardized agricultural information service network platform, giving full play to the basic function of information center. Establishing the agricultural products logistics center which combines synthesizing type and career oriented type as one with high starting point, improving its capacities of storage, information development, processing, utilization etc. giving logistics centers the function of information nodes. Establishing and choosing the logistics center nodes must be according to the situation of agricultural industrialization development in different regions so as to organize the production and processing of agricultural products systematically. Only realizing several supplies and purchasing of agricultural products can the rapid development of the agricultural products logistics be effectively promoted. The higher the agricultural information transparency is, the faster the speed of propagation is, the higher the accuracy of information is, the greater the amount of information is, the reasonable and timely adjustment of agricultural industry structure more can be promoted. Optimizing the agricultural industrial production and marketing chain configuration to promote the change of traditional agricultural production mode into the order oriented agricultural production mode.

c). Establishing agricultural products management system in logistics. After mass investigations it can be found that it does exist a lot of invalid logistics in our agricultural products. In international competition, on the road of our country's gradually introducing electronic commerce, the forms of China all rely on the management system of agricultural products logistics, the uppermost one is the requirements on packaging standardization. So now at the part of electronic commerce logistics, the market access system needs to be practiced and management system related to the quality needs to be further strengthened to effectively prevent the intrusion of harmful things and promote the development of China's agricultural products to be more health, at the same time guarantee the export of agricultural products of China, strengthen the application of import and export trade in e-commerce.

d). Focusing on the construction of modern agricultural products logistics, improving its infrastructure development. Speeding up the construction of large and medium-sized logistics centers with an integration of comprehensiveness and professional property, improving the supporting infrastructure, increasing the logistics transportation road construction to build a national agricultural products logistics system with modern characteristic. Strengthening the construction of agricultural products market infrastructure and agricultural market information to realize the informational 
development of agricultural products trade and management. Establishing perfect cold chain system to ensure the quality of agricultural products as well as distribution services.

\section{Conclusion}

The development of agricultural products logistics industry in our country has a relation to the approaching footsteps of our country's agricultural modernization, to the construction of agricultural scale management, to the economic income of farmers, food safety problems as well as the development of the comprehensive strength of cities, regions and even the nation. We must attach great importance to the development of the agricultural products logistics, attach great importance to the combination of the actual status of the national and local agricultural production when developing agricultural products logistics construction. We must make full use of the emerging e-commerce platform to solve the problems existing in the agricultural products logistics development in our country as soon as possible. Innovating the agricultural products logistics mode to promote our country's agricultural products logistics mode to be changed from the traditional pattern into modern pattern. Promoting the modernization process of agricultural production, increasing farmer's income. Promoting the comprehensive strength development and construction of our country and regions.

\section{Acknowledgments}

Project name: Agricultural products logistics mode optimization research based on integration of Beijing-Tian Jin-Heibei Area, the project is funded by by the Tianjin institution of higher learning humanities and social science research project; Serial number: 20142410.

\section{References}

[1] Zhang Ping, Wang Jian. The successful experience and enlightenment of foreign agricultural products logistics development, Journal of Daqing Normal University, 2008 (4).

[2] Gao Zengguang. Philosophy thinking on agricultural industrialization and Chinese modernization construction, Journal of Brand (theory monthly), 2010 (05).

[3] Hong-tao Zhang. Some countermeasures on agricultural products electronic commerce development, Journal of information construction, 2010 (02).

[4] Zhangyu: Jilin province optimization pattern and development countermeasures research of agricultural products logistics, Military Science and Technology College, 2009, 6.

[5] Li Xuewei etc. China logistics transaction model research, Beijing: Tsinghua University press, 1st version, 2004, 4. 